\title{
Minute Times Picomole per Milliliter
}

National Cancer Institute

\section{Source}

National Cancer Institute. Minute Times Picomole per Milliliter. NCI Thesaurus. Code C85735.

Minutes times picomoles per milliliter. 